TELAGA BAHASA

Volume 5

No. 2 Desember 2017

Halaman 193-212

\title{
MAKNA TOPIK 'WARISAN' DALAM UNGGAHAN FACEBOOK AFI NIHAYA FARADISA: ANALSIS WACANA KRITIS
}

\section{(The Meaning Of “Warisan" in Afi Nihaya Faradisa's Upload on Facebook: Critical Discourse Analysis)}

\author{
Ali Kusno \\ Wenni Rusbiyantoro \\ Kantor Bahasa Kalimantan Timur, Balai Bahasa Jawa Timur \\ Pos.el: alikusnolambung@gmail.com,wenni_indiecard@yahoo.com
}

\begin{abstract}
Abstrak
Afi Nihaya Faradisa seorang siswa SMA Negeri 1 Gambiran Bayuwangi yang mencuri perhatian masyarakat Indonesia pada bulan Mei 2017. Unggahan Afi di Facebook berjudul 'Warisan' inilah yang mendapat perhatian besar dari masyarakat sekaligus memicu perdebatan pengguna media sosial. Perdebatan terkait pemaknaan dalam unggahan tersebut. Oleh karena itu, perlu dilakukan kajian untuk mengungkapkan makna sebenarnya unggahan Afi. Penelitian ini bertujuan mengungkapkan makna yang terkandung dalam unggahan Afi berjudul “Warisan'. Penelitian ini menggunakan analisis wacana kritis Model Fairclough. Data penelitian diambil dari unggahan Afi di Facebook berjudul 'Warisan'. Teknik analisis data menggunakan model interaktif. Hasil penelitian menunjukkan bahwa Afi mengajak seluruh bangsa Indonesia untuk menjaga toleransi khususnya di media sosial yang rawan terjadinya gesekan-gesekan antarpengguna. Afi menyoroti tentang identitas, seperti agama, suku, ras, maupun kebangsaan yang merupakan warisan dari orang tua. Afi juga mengajak seluruh rakyat Indonesia untuk menghayati Pancasila, Undang-Undang Dasar 1945, dan juga semboyan Bhinneka Tunggal Ika agar kehidupan toleransi beragama tetap terjaga.
\end{abstract}

Kata kunci:Afi Nihaya Faradisa, warisan, analisis wacana kritis

\footnotetext{
Abstract

Afi N.F., a student of SMA Negeri 1 Gambiran Bayuwangi had been stolen the attention of the Indonesian people in May 2017. Afi N.F. upload an article on Facebook titled 'Warisan' is getting massive attention from the community and at the same time triggered the debates among social media users. This study aimed to express the meaning contained in the article. This
} 
research used critical discourse analysis of Fairclough Model. The research data was taken from the triggered titled "Warisan". Data analysis technique using an interactive model. The results showed a significant message to all the Indonesian nation to maintain tolerance, especially in social media that is prone to friction among its users. In the article, Afi had been highlighting the issues of identity, such as religion, ethnicity, race, and nationality are inherited from parents, as she stated in her writing. Afi also invites all the people of Indonesia to live the Pancasila, the 1945 Constitution, and also the motto of Bhinneka Tunggal Ika so the life of religious tolerance will be maintained.

Keywords: Afi Nihaya Faradisa, Heritage, Critical Discourse Analysis

\section{PENDAHULUAN}

Afi Nihaya Faradisa (Afi) seorang siswa SMA Negeri 1 Gambiran Banyuwangi berhasil mendapat perhatian masyarakat Indonesia pada bulan Mei 2017 melalui unggahan-unggahannya di media sosial Facebook. Umur Afi masih 18 tahun dan masih duduk di bangku SMA. Afi terkenal di tengah-tengah memanasnya suasana bangsa Indonesia setelah rangkaian Pilkada DKI Jakarta 2017. Tulisan-tulisan Afi di Facebook mampu menginspirasi banyak orang dan tidak sedikit juga yang justru menuai kecaman (Dhanu, 2017). Banyak pengguna internet yang menganggap statusstatus yang dibuat Afi di Facebook cukup mengena dengan konteks perkembangan sosial di Indonesia saat itu. Banyak yang tidak menyangka, remaja seusia Afi bisa menulis pemikiran yang kritis. Meskipun dalam perkembangannya ,ada isu yang memojokkan Afi telah melakukan plagiasi.
Terlepas dari isu yang berkembang, penggunaan bahasa dalam media sosial khususnya Facebook Afi menarik untuk dikaji.

Media sosial saat ini memang menjadi ajang segala hal untuk diperdebatkan. Setiap orang bebas berpendapat dan membuat unggahan. Akibatnya, banyak terjadi silang pendapat dan perdebatan antarpengguna media sosial. Hal itu secara tidak langsung menumbuhkan bibit-bibit kebencian sesama warga (pengguna media sosial). Konflik linguistik dalam media sosial dapat memicu konflik sosial (nyata) apabila dikaitkan dengan isu keagamaan (Kusno, 2017:104). Pengguna media sosial seolah juga tidak pernah kehabisan alasan untuk saling membenci dan menyerang kelompok lain yang berseberangan. Aksi saling serang pernyataan di media sosial dilatarbelakangi perbedaan 
pandangan politik yang dikaitkan dengan isu SARA.

Afi juga menulis perihal keberagaman di Indonesia. Afi mengunggah tulisan dengan memberi judul tulisan 'Warisan'. Unggahan 'Warisan' inilah yang mendapat perhatian besar dari masyarakat sekaligus kembali memicu perdebatan pengguna media sosial. Akun Facebook Afi diblokir (Rachelea, 2017). Akun itu tidak bisa dibuka setelah menulis status terkait keberagaman yang berjudul 'Warisan'. Dalam statusnya tersebut, Afi berbicara bahwa kewarganegaraan, nama, dan agama adalah warisan. Oleh karena itu, menarik untuk membuat kajian terhadap tulisan tersebut untuk mengungkap makna yang terkandung dalam tulisan Afi. Dengan demikian, akan ditemukan letak kebenaran maupun ketidaktepatan isi tulisan yang disampaikan Afi dalam akun Facebook-nya.

\section{TEORI}

Penelitian ini menggunakan analisis wacana. Menurut Djajasudarma (1993: 75), prinsip penafsiran dapat terjadi melalui penafsiran lokal (termasuk ruang dan waktu) dan prinsip analogi dalam menafsirkan pengertian (makna) yang terkandung dalam wacana. Dengan analisis wacana dapat dipahami bahwa "...discourse a word that constructs language as active: texts and talks in social practice" (Hepburn \& Potter, 2007). Untuk dapat mengidentifikasi pemaknaan unggahan Facebook Afi berjudul 'Warisan' menggunakan analisis wacana yang digunakan analisis wacana kritis Model Fairclough.

Teks pemaknaan unggahan Facebook Afi berjudul 'Warisan' merupakan sebuah wacana. Menurut Purbani (2009: 1) istilah wacana memiliki pengertian yang beragam tergantung pada konteks apa yang tengah digunakan untuk memperbincangkannya. Secara umum wacana dimengerti sebagai pernyataan-pernyataan. Dalam ranah linguistik, wacana dipahami sebagai unit kebahasaan yang lebih besar daripada kata atau kalimat, yang dapat melibatkan satu atau lebih orang. Jadi, sebuah pidato, dialog, polemik, perdebatan, percakapan atau perbincangan dapat dikategorisasikan sebagai sebuah wacana.

Crystal dan Cook dalam Nunan (Purbani, 2009: 2) mendefinisikan wacana sebagai unit bahasa lebih besar daripada kalimat, sering berupa satuan yang runtut/koheren dan memiliki tujuan dan konteks tertentu, seperti ceramah agama, argumen, lelucon, atau cerita. Nunan melihat unsur-unsur keruntutan dan koherensi sebagai hal yang penting untuk menilai sebuah wacana. Lubis (Purbani, 2009: 2) mendefinisikan wacana sebagai kumpulan 
pernyataan-pernyataan yang ditulis atau diucapkan atau dikomunikasikan dengan menggunakan tanda-tanda.

Istilah wacana yang digunakan dalam Critical Discourse Analysis (CDA) salah satunya dikembangkan ahli linguistik sosial seperti Norman Fairclough. Analisis wacana kritis Model Fairclough menempatkan wacana atau penggunaan bahasa sebagai praktik sosial; wacana atau penggunaan bahasa dihasilkan dalam sebuah peristiwa diskursif tertentu; wacana yang dihasilkan berbentuk sebuah genre tertentu (Ahmadi F., 2014: 255).

Apabila dikaitkan dengan penelitian ini, analisis wacana kritis Model Fairchlough menempatkan wacana atau penggunaan bahasa dalam pemaknaan unggahan Facebook Afi berjudul 'Warisan' sebagai praktik sosial. Penafsiran wacana ini tidak bisa dilepaskan dari konteks sosial budaya bangsa Indonesia. Wacana atau penggunaan pemaknaan unggahan Facebook Afi berjudul 'Warisan' dihasilkan dalam sebuah peristiwa diskursif tertentu. Peristiwa diskursif itu dapat dipahami bahwa wacana yang dihasilkan merepresentasikan wacana yang berkembang dan tersebar dalam kehidupan bangsa Indonesia. Penggunaan bahasa Indonesia dalam wacana pemaknaan unggahan Facebook Afi berjudul 'Warisan' juga dapat diidentifikasi genre atau jenis berdasarkan bentuknya.

Analisis wacana kritis model Fairclough dikenal dengan sebutan analisis tiga dimensi. Analisis tiga dimensi ini ialah analisis tekstual (level mikro) adalah, 1) analisis deskriptif terhadap dimensi teks; 2) analisis praktik wacana (level meso) adalah analisis interpretatif terhadap pemproduksian, penyebaran, dan pengonsumsian wacana, termasuk intertekstualitas dan interdiskursivitas; 3) analisis sosiokultural (level makro) adalah analisis eksplanatif terhadap konteks sosiokultural yang melatarbelakangi kemunculan sebuah wacana (Fairclough dalam Ahmadi F., 2014: 255). Analisis dengan tiga dimensi tersebut akan dapat mengungkap pemaknaan sebuah wacana dalam pemaknaan unggahan Facebook Afi berjudul 'Warisan' dengan lebih menyeluruh dan mendalam.

Analisis wacana kritis model Fairclough efektif dalam mengungkapkan pemaknaan sebuah wacana media sosial. Penelitian terkait penggunaan analisis wacana kritis model Fairclough dalam pengungkapan makna wacana dalam media sosial khususnya Facebook telah dilakukan Kusno dalam penelitian berjudul Discourse Analysis of Citizens Conversation in Facebook Grup Called 'Bubuhan 
Samarinda': Identification of Potential Social konflict (Kusno, 2017b). Dalam penelitian tersebut dapat diungkapkan representasi makna dalam percakapan warga dalam grup Facebook Bubuhan Samarinda. Penelitian lain yang juga terkait, yakni tentang representasi makna dalam penelitian Budiwati (2011) dengan pendekatan analisis wacana kritis mampu mengungkapkan representasi wacana gender dalam ungkapan berbahasa Indonesia dan bahasa Inggris.

\section{METODE}

Penelitian ini menggunakan metode kualitatif yang bersifat deskriptif. Metode penelitian kualitatif merupakan prosedur penelitian yang menghasilkan data deskriptif berupa kata-kata tertulis dan lisan tentang sifat individu, keadaan, gejala dari kelompok tertentu yang dapat diamati (Moleong, 1994: 6). Objek penelitian ini adalah penggunaan bahasa dalam pemaknaan unggahan Facebook Afi berjudul 'Warisan' (Faradisa, 2017). Data dan sumber data yang digunakan dalam penelitian ini berupa dokumen dalam unggahan Facebook Afi berjudul 'Warisan' yang diunggah pada tanggal 15 Mei 2017 (Faradisa, 2017). Teknik analisa data menggunakan model interaktif (Miles \& Huberman, 1992: 19-20), yang terdiri atas tiga komponen analisis, yaitu reduksi data, sajian data, dan penarikan simpulan atau verifikasi. Aktivitas ketiga komponen itu dilakukan dalam bentuk interaktif dengan proses pengumpulan data.

\section{HASIL PEMBAHASAN}

Berikut ini analisis wacana kritis terhadap unggahan Afi berjudul 'Warisan' untuk mengungkapkan representasi makna yang ditimbulkan.

\section{Analisis Tekstual (Analisis Mikro) \\ a. Struktur Teks}

Secara umum struktur penggunaan bahasa unggahan Afi dalam unggahan Facebook yang berjudul 'Warisan' dalam analisis ini, dibagi menjadi tiga bagian, yaitu bagian pembuka, bagian isi, dan bagian penutup.

Bagian Pembuka. Sebuah judul dapat memberikan gambaran isi dari keseluruhan sebuah wacana. Pilihan kata yang digunakan dalam judul tentunya sangat memengaruhi makna yang disampaikan kepada pembaca. Selain itu, pilihan judul juga dapat menumbuhkan keingintahuan pembaca.

(1) WARISAN

Ditulis oleh Afi Nihaya Faradisa

Kebetulan saya lahir di Indonesia dari pasangan muslim, maka saya beragama Islam. Seandainya saja saya lahir di Swedia atau Israel dari keluarga Kristen atau Yahudi, apakah ada jaminan 
bahwa hari ini saya memeluk Islam sebagai agama saya? Tidak. Saya tidak bisa memilih dari mana saya akan lahir dan di mana saya akan tinggal setelah dilahirkan. Kewarganegaraan saya warisan, nama saya warisan, dan agama saya juga warisan.

Unggahan Afi menggunakan judul 'Warisan'. Makna Warisan tersebut kemudian dibangun dalam wacana selanjutnya. Pada bagian awal tulisan, dibuka dengan pengantar dengan paragraf pembuka.

Dalam paragraf pembuka tersebut Afi mengungkapkan pandangan bahwa dirinya secara kebetulan lahir di Indonesia dari orang tua yang beragama muslim. Afi pun beragama Islam. Afi mengandaikan dirinya lahir di Swedia atau Israel dari keluarga Kristen atau Yahudi, apakah ada jaminan bahwa hari ini dirinya memeluk Islam sebagai agama. Afi merasa dirinya tidak bisa memilih dari mana akan lahir dan di mana akan tinggal setelah dilahirkan. Kewarganegaraan merupakan warisan, nama sebuah warisan, dan agama juga warisan. Dalam paragraf pembuka tersebut Afi menekankan bahwa kewarganegaraan merupakan warisan, nama sebuah warisan, dan agama juga warisan.

Pemaparan Isi. Setelah membuka dengan gambaran perihal 'Warisan'
Unggahan Afi yang berjudul 'Warisan' memaparkan isi sebagai berikut ini.

a) Agama, ras, suku, dan kebangsaan kita adalah warisan

(2) Untungnya, saya belum pernah bersitegang dengan orang-orang yang memiliki warisan berbedabeda karena saya tahu bahwa mereka juga tidak bisa memilih apa yang akan mereka terima sebagai warisan dari orangtua dan negara. Setelah beberapa menit kita lahir, lingkungan menentukan agama, ras, suku, dan kebangsaan kita. Setelah itu, kita membela sampai mati segala hal yang bahkan tidak pernah kita putuskan sendiri.

Berdasarkan uraian tersebut dapat dipahami bahwa Afi berpandangan bahwa sebuah keberuntungan dirinya belum pernah bersitegang dengan orang-orang yang memiliki warisan (latar belakang) berbedabeda. Afi mengetahui bahwa dirinya juga tidak bisa memilih hal yang akan diterima sebagai warisan dari orang tua dan negara. Setelah beberapa menit terlahir, lingkungan menentukan agama, ras, suku, dan kebangsaan seseorang. Setelah itu, masingmasing orang akan membela sampai mati segala hal yang bahkan tidak pernah diputuskan itu. 
b) Masing-masing agama mendoktrin agama mereka yang paling benar

Afi berpandangan bahwa masingmasing agama mendoktrin agamanya sebagai ajaran yang paling benar.

(3) Sejak masih bayi saya didoktrin bahwa Islam adalah satu-satunya agama yang benar. Saya mengasihani mereka yang bukan muslim, sebab mereka kafir dan matinya masuk neraka. Ternyata,teman saya yang Kristen juga punya anggapan yang sama terhadap agamanya. Mereka mengasihani orang yang tidak mengimani Yesus sebagai Tuhan, karena orang-orang ini akan masuk neraka, begitulah ajaran agama mereka berkata.

Berdasarkan uraian tersebut dapat dipahami bahwa Afi berpandangan bahwa sejak masih bayi dirinya didoktrin bahwa Islam adalah satu-satunya agama yang benar. Afi mengasihani orang-orang yang bukan muslim. Orang-orang kafir dan matinya masuk neraka. Ternyata, teman Afi yang beragama Kristen juga mempunyai anggapan yang sama terhadap agamanya. Teman Afi yang beragama Kristen mengasihani orang yang tidak mengimani Yesus sebagai Tuhan karena orang-orang ini akan masuk neraka, begitulah ajaran agama.

\section{c) Masing-masing umat beragama tidak akan ada titik temu}

Afi berpandangan bahwa masingmasing umat beragama tidak akan ada titik temu seperti dalam penggalan unggahan berikut ini.

(4) Maka, bayangkan jika kita tak henti menarik satu sama lainnya agar berpindah agama, bayangkan jika masing-masing umat agama tak henti saling beradu superioritas seperti itu, padahal tak akan ada titik temu. Jalaluddin Rumi mengatakan, "Kebenaran adalah selembar cermin di tangan Tuhan; jatuh dan pecah berkeping-keping. Setiap orang memungut kepingan itu, memperhatikannya, lalu berpikir telah memiliki kebenaran secara utuh."

Berdasarkan uraian tersebut dapat dipahami bahwa Afi berpandangan bahwa setiap pemeluk agama tidak henti menarik satu sama lainnya agar berpindah agama. Bayangkan jika masing-masing umat agama tidak henti saling beradu superioritas seperti itu padahal tidak pernah ada titik temu. Afi mengutip Jalaluddin Rumi yang menyatakan bahwa kebenaran adalah selembar cermin di 
tangan Tuhan; jatuh dan pecah berkepingkeping. Setiap orang memungut kepingan itu, memperhatikannya, lalu berpikir telah memiliki kebenaran secara utuh.

d) Tidak perlu melabeli orang masuk surga atau neraka

Afi mengungkapkan bahwa tidak perlu melabeli orang masuk surga ataupun neraka seperti dalam penggalan unggahan berikut ini.

(5) Salah satu karakteristik umat beragama memang saling mengklaim kebenaran agamanya. Mereka juga tidak butuh pembuktian, namanya saja "iman". Manusia memang berhak menyampaikan ayat-ayat Tuhan, tapi jangan sesekali mencoba jadi Tuhan. Usah melabeli orang masuk surga atau neraka sebab kita pun masih menghamba.

Berdasarkan uraian tersebut dapat dipahami bahwa Afi berpandangan bahwa salah satu karakteristik umat beragama memang saling mengklaim kebenaran agamanya. Masing-masing penganut agama juga tidak membutuhkan pembuktian sebagai bentuk keimanan seseorang. Manusia memang berhak menyampaikan ayat-ayat Tuhan, tetapi jangan sesekali mencoba jadi Tuhan. Tidak usah melabeli seseorang masuk surga atau neraka sebab manusia pun masih menjadi hamba Tuhan.

\section{e) Latar belakang perselisihan karena saling klaim}

Afi menuturkan bahwa latar belakang perselisihan karena saling klaim seperti dalam penggalan unggahan berikut ini.

(6) Latar belakang dari semua perselisihan adalah karena masing-masing warisan mengklaim, "Golonganku adalah yang terbaik karena Tuhan sendiri yang mengatakannya.

Berdasarkan uraian tersebut dapat dipahami bahwa Afi berpandangan latar belakang dari semua perselisihan adalah karena masing-masing warisan mengklaim, golongan masing-masing adalah yang terbaik karena Tuhan sendiri yang mengatakannya.

f) Apabila Tuhan mau kita akan disamakan dalam segala hal

Afi menuturkan bahwa apabila Tuhan berkenan pastilah manusia akan disamakan dalam segala hal. Hal itu seperti dalam penggalan unggahan berikut ini.

(7) Lantas, pertanyaan saya adalah kalau bukan Tuhan, siapa lagi yang menciptakan para Muslim, Yahudi, Nasrani, Buddha, Hindu, bahkan ateis dan memelihara mereka semua sampai hari ini? Tidak ada yang meragukan 
kekuasaan Tuhan. Jika Dia mau, Dia bisa saja menjadikan kita semua sama. Serupa. Seagama. Sebangsa. Tapi tidak, kan?

Berdasarkan uraian tersebut dapat dipahami bahwa Afi berpandangan kalau bukan Tuhan, siapa lagi yang menciptakan para Muslim, Yahudi, Nasrani, Buddha, Hindu, bahkan ateis dan memelihara semuanya sampai saat ini. Tidak ada yang meragukan kekuasaan Tuhan. Jika Tuhan berkenan, bisa saja menjadikan semua sama, seagama, dan sebangsa.

g) Kesamaan dan keragaman tidak menjamin kerukunan

Afi menuturkan bahwa kesamaan dan keragaman tidak menjamin kerukunan seperti dalam penggalan unggahan berikut ini.

(8) Apakah jika suatu negara dihuni oleh rakyat dengan agama yang sama, hal itu akan menjamin kerukunan? Tidak! Nyatanya, beberapa negara masih rusuh juga padahal agama rakyatnya sama. Sebab, jangan heran ketika sentimen mayoritas vs. minoritas masih berkuasa, maka sisi kemanusiaan kita mendadak hilang entah kemana.

Berdasarkan uraian tersebut dapat dipahami bahwa Afi mempertanyakan jika suatu negara dihuni oleh rakyat dengan agama yang sama tidak menjamin adanya kerukunan. Buktinya, beberapa negara masih rusuh juga padahal agama rakyatnya sama. Oleh karena itu, jangan heran ketika sentimen mayoritas dengan minoritas masih berkuasa dapat mengakibatkan sisi kemanusiaan seseorang mendadak hilang.

h) Apabila masing-masing memaksakan kitab suci sebagai dasar negara, akan timbul perpecahan

Afi menuturkan bahwa apabila masing-masing memaksakan kitab suci sebagai dasar negara dapat mengakibatkan perpecahan seperti diungkapkan Afi dalam unggahan berikut ini.

(9) Bayangkan juga seandainya masing-masing agama menuntut agar kitab sucinya digunakan sebagai dasar negara. Maka, tinggal tunggu saja kehancuran Indonesia kita. Karena itulah yang digunakan negara dalam mengambil kebijakan dalam bidang politik, hukum, atau kemanusiaan bukanlah Alquran, Injil, Tripitaka, Weda, atau kitab suci sebuah agama, melainkan Pancasila, Undang-Undang Dasar '45, dan semboyan Bhinneka Tunggal Ika. 
Berdasarkan uraian tersebut dapat dipahami bahwa Afi mengajak bangsa Indonesia untuk membayangkan seandainya masing-masing agama menuntut agar kitab sucinya digunakan sebagai dasar negara. Menurut Afi apabila itu terjadi, tinggal menunggu kehancuran bangsa Indonesia. Oleh karena itu, yang digunakan negara dalam mengambil kebijakan dalam bidang politik, hukum, atau kemanusiaan bukanlah Alquran, Injil, Tripitaka, Weda, atau kitab suci sebuah agama, melainkan Pancasila, Undang-Undang Dasar 1945, dan semboyan Bhinneka Tunggal Ika.

\section{i) Kebebasan beragama dijamin Pancasila}

Afi menuturkan bahwa kebebasan beragama dijamin dalam Pancasila seperti dalam penggalan unggahan berikut.

(10) Dalam perspektif Pancasila, setiap pemeluk agama bebas meyakini dan menjalankan ajaran agamanya, tapi mereka tak berhak memaksakan sudut pandang dan ajaran agamanya untuk ditempatkan sebagai tolok ukur penilaian terhadap pemeluk agama lain. Hanya karena merasa paling benar, umat agama $A$ tidak berhak mengintervensi kebijakan suatu negara yang terdiri dari bermacam keyakinan.

Berdasarkan uraian tersebut dapat dipahami bahwa Afi berpandangan dalam perspektif Pancasila, setiap pemeluk agama bebas meyakini dan menjalankan ajaran agamanya. Meskipun demikian, setiap pemeluk agama tidak berhak memaksakan sudut pandang dan ajaran agamanya untuk ditempatkan sebagai tolok ukur penilaian terhadap pemeluk agama lain. Atas pertimbangan merasa paling benar, umat salah satu agama tidak berhak mengintervensi kebijakan suatu negara yang terdiri atas bermacam keyakinan.

Penutup

menggunakan argumentatif. Afi dalam penutup unggahan 'Warisan' menggunakan argumentatif untuk menetralkan isu-isu negatif dengan kalimat positif dan persuasif sebagai berikut.

\section{a) Suatu saat kita akan bercerita keributan bangsa kepada anak cucu}

Afi mengajak pembaca untuk merenung bahwa suatu saat bangsa Indonesia akan bercerita keributan bangsa kepada anak cucu, seperti dalam penggalan berikut ini.

(11) Suatu hari di masa depan, kita akan menceritakan pada anak сиси kita betapa negara ini nyaris tercerai-berai bukan karena bom, senjata, peluru, atau rudal, tapi karena orang- 
orangnya saling mengunggulkan

bahkan meributkan warisan masing-masing di media sosial.

Ketika negara lain sudah pergi ke bulan atau merancang teknologi yang memajukan peradaban, kita masih sibuk meributkan soal warisan.

Berdasarkan uraian tersebut dapat dipahami bahwa Afi berpandangan suatu hari pada masa depan, bangsa Indonesia akan menceritakan pada anak cucu betapa negara ini nyaris tercerai-berai bukan karena bom, senjata, peluru, atau rudal. Tercerai-berainya negara Indonesia justru karena orangorangnya saling mengunggulkan bahkan meributkan 'warisan' masing-masing di media sosial. Ketika negara lain sudah pergi ke bulan atau merancang teknologi yang memajukan peradaban, bangsa Indonesia masih sibuk meributkan soal warisan tersebut.

b) Bangsa Indonesia tidak harus berpikiran sama, tetapi sama-sama berpikir

Afi mengajak bangsa Indonesia untuk tidak harus berpikirab sama, tetapi untuk sama-sama berpikir. Seperti dalam penggalan unggahan berikut ini.

(12) Kita tidak harus berpikiran sama, tapi marilah kita samasama berpikir.
Berdasarkan uraian tersebut dapat dipahami bahwa Afi berpandangan bangsa Indonesia tidak harus berpikiran sama, tetapi mau untuk sama-sama berpikir.

\section{b. Penggunan Gramatika Transitif}

Dalam bagian tata bahasa menurut Fairclough dalam Yusep Ahmadi F., 2014: 257), ada tiga aspek yang bisa dianalisis, yakni ketransitifan, tema, dan modalitas. Ketransitifan berkenaan dengan fungsi ideasional bahasa, tema berkenaan dengan fungsi tekstual bahasa, dan modalitas berkenaan dengan fungsi interpersonal bahasa (Eriyanto dalam Yusep Ahmadi F., 2014: 257). Gramatika yang berupa transitivitas, Afi menggunakan strategi dengan menguatkan hal positif dan mengurangi hal negatif intoleransi.

\section{c. Penggunaan Kosakata}

Afi Nihaya Farahisa memiliki cara tersendiri untuk mengajak anak-anak muda yang memahami teknologi untuk menjaga persatuan dan kesatuan bangsa. Unggahan Afi dalam penggunaan kosakata menggunakan beberapa pola sebagai berikut.

Pertanyaan retoris. Gaya bahasa pertanyaan retoris adalah semacam pertanyaan yang dipergunakan dalam pidato atau tulisan dengan tujuan untuk mencapai efek lebih mendalam dan penekanan wajar, dan sama sekali tidak menghendaki adanya suatu jawaban (Keraf, 2007: 134). Berikut ini 
penggunaan gaya bahasa retoris dalam unggahan Afi yang berjudul 'Warisan'

(13) Kebetulan saya lahir di Indonesia dari pasangan muslim, maka saya beragama Islam. Seandainya saja saya lahir di Swedia atau Israel dari keluarga Kristen atau Yahudi, apakah ada jaminan bahwa hari ini saya memeluk Islam sebagai agama saya? Tidak.

(14) .. Lantas, pertanyaan saya adalah kalau bukan Tuhan, siapa lagi yang menciptakan para Muslim, Yahudi, Nasrani, Buddha, Hindu, bahkan ateis dan memelihara mereka semua sampai hari ini?

Tidak ada yang meragukan kekuasaan Tuhan. Jika Dia mau, Dia bisa saja menjadikan kita semua sama. Serupa. Seagama. Sebangsa. Tapi tidak, kan?

\section{(15) ... Apakah jika suatu negara} dihuni oleh rakyat dengan agama yang sama, hal itu akan menjamin kerukunan? Tidak! Nyatanya, beberapa negara masih rusuh juga padahal agama rakyatnya sama.

Berdasarkan data (13) Afi menggunakan pertanyaan retoris berupa apakah ada jaminan bahwa hari ini saya memeluk Islam sebagai agama saya? Selanjutnya pada data (14) Afi menggunakan pertanyaan retoris siapa lagi yang menciptakan para Muslim, Yahudi, Nasrani, Buddha, Hindu, bahkan ateis dan memelihara mereka semua sampai hari ini?Sedangkan pada data (15), Afi menggunakan pertanyaan retoris ... Apakah jika suatu negara dihuni oleh rakyat dengan agama yang sama, hal itu akan menjamin kerukunan? Pertanyaan-pertanyaan retoris itu dipergunakan Afi dalam unggahan 'Warisan' berupa tulisan dengan tujuan untuk mencapai efek lebih mendalam dan menekan, tetapi tidak menghendaki adanya suatu jawaban.

Penggunaan repetisi. Repetisi adalah perulangan bunyi, suku kata, kata atau bagian kalimat yang dianggap penting untuk memberi tekanan dalam sebuah konteks yang sesuai (Keraf, 2007: 127). Berikut ini penggunaan gaya bahasa repetisi dalam unggahan Afi yang berjudul 'Warisan'.

(16) Kewarganegaraan saya warisan, nama saya warisan, dan agama saya juga warisan.

(17) Saya tidak bisa memilih dari mana saya akan lahir dan di mana saya akan tinggal setelah dilahirkan.

(18) ... Maka, bayangkan jika kita tak henti menarik satu sama lainnya agar berpindah agama, 
bayangkan jika masing-masing umat agama tak henti saling beradu superioritas seperti itu, padahal tak akan ada titik temu.

Berdasarkan data (16) Afi menggunakan repetisi berupa pengulangan kata warisan. Dalam data (17) Afi menggunakan pengulangan berupa kata dari mana saya akan. Dalam data (18) Afi menggunakan pengulangan berupa kata bayangkan. Pengulangan kata-kata itu memberikan penekanan kata dalam bagian kalimat yang digunakan.

Gaya bahasa hiperbola. Hiperbol adalah gaya bahasa yang mengandung suatu pernyataan yang berlebihan dengan membesar-besarkan suatu hal (Keraf, 2007: 135). Berikut ini penggunaan gaya bahasa hiperbola dalam unggahan Afi yang berjudul 'Warisan'.

(19) Setelah beberapa menit kita lahir, lingkungan menentukan agama, ras, suku, dan kebangsaan kita. Setelah itu, kita membela sampai mati segala hal yang bahkan tidak pernah kita putuskan sendiri.

Berdasarkan data menggunakan hiperbola berupa penggunaan membela sampai mati. Penggunaan ungkapan tersebut merupakan efek berlebihan dalam unggahan Afi.
Penggunaan metafora. Metafora adalah semacam analogi membandingkan dua hal secara langsung, tetapi dalam bentuk yang singkat. Berikut ini penggunaan gaya bahasa metafora dalam unggahan Afi yang berjudul 'Warisan'.

(20) Latar belakang dari semua perselisihan adalah karena masing-masing warisan mengklaim, "Golonganku adalah yang terbaik karena Tuhan sendiri yang mengatakannya".

(21) Bayangkan juga seandainya masing-masing agama menuntut agar kitab sucinya digunakan sebagai dasar negara. Maka, tinggal tunggu saja kehancuran Indonesia kita.

Berdasarkan data (20) Afi menggunakan metafora berupa penggunaan metafora Warisan. Selanjutnya, pada data (21) Afi menggunakan metafora kehancuran Indonesia kita.

Penggunaan ironi. Ironi adalah suatu acuan yang ingin mengatakan sesuatu dengan kata atau maksud berlainan dari apa yang terkadung dalam rangkaian kata-katanya. Ironi akan berhasil kalau pembaca juga sadar maksud yang disembunyikan di balik rangkaian kata-katanya (Keraf, 2007: 143). Berikut ini penggunaan gaya bahasa ironi 
dalam unggahan Afi yang berjudul 'Warisan'.

(22) Suatu hari di masa depan, kita akan menceritakan pada anak cucu kita betapa negara ini nyaris tercerai-berai bukan karena bom, senjata, peluru, atau rudal, tapi karena orangorangnya saling mengunggulkan bahkan meributkan warisan masing-masing di media sosial.

Berdasarkan data (22) Afi menggunakan ironi bahwa suatu hari di masa depan, bangsa Indonesia akan menceritakan pada anak cucu bahwa Indonesia nyaris tercerai-berai bukan karena bom, senjata, peluru, atau rudal. Ancaman perpecahan karena ulah keegoisan orang-orang saling meributkan latar belakang agama, kesukuan, dan lainnya di media sosial. Pernyataan itu merupakan sindirikan bagi orang-orang yang sibuk meributkan latar belakang diri dan menyerang sekaligus memojokkan pihak lain. Hal itulah yang tidak disadari dapat merusak persatuan dan kesatuan bangsa Indonesia.

\section{Penggunaan sinisme.} Sinisme diartikan sebagai suatu sindirian yang berbentuk kesangsian yang mengandung ejekan terhadap keikhlasan dan ketulusan hati (Keraf, 2007: 143). Berikut ini penggunaan gaya bahasa sinisme dalam unggahan Afi yang berjudul 'Warisan'.

(23) Ketika negara lain sudah pergi ke bulan atau merancang teknologi yang memajukan peradaban, kita masih sibuk meributkan soal warisan.

(24) Kita tidak harus berpikiran sama, tapi marilah kita samasama berpikir.

Sebagai suatu sindirian yang berbentuk kesangsian yang mengandung ejekan terhadap keikhlasan dan ketulusan hati. Pernyataan seperti dalam data (23) merupakan sindirian bagi orang-orang yang selalu menebar kebencian. Ketika negara lain sudah pergi ke bulan atau merancang teknologi yang memajukan peradaban, sebagian dari bangsa Indonesia masih sibuk meributkan soal warisan. Sindirian selanjutnya, seperti dalam data (24) bahwa bangsa Indonesia tidak harus berpikiran sama, tetapi Afi mengajak (pembaca) untuk bersama-sama berpikir. Pernyataan mari sama-sama berpikir merupakan sindiran bagi pihak-pihak yang selalu mengabaikan pikirannya dan terus mempermasalahkan latar belakang orang lain dalam konteks bernegara.

\section{Dimensi Praktik Wacana}

Analisis teks dilanjutkan pada analisis praktik wacana. Menurut Failrlough (dalam 
Jorgensn dan Philips dalam Yusep Ahmadi F. 2014: 261). Analisis praktik kewacanaan ini dipusatkan pada bagaimana teks diproduksi dan dikonsumsi, termasuk di dalamnya menyelisik proses yang dilalui suatu teks sebelum dicetak dan perubahan apa yang dialami sebelum disebarluaskan.

Setelah tulisannya yang berjudul 'Warisan' viral, Afi diundang dalam berbagai acara dan kegiatan. Afi mengungkap latar belakangnya membuat tulisan berjudul 'Warisan'. Kondisi lingkungan sosial yang tidak kondusif dan nyaris terjadi perpecahan karena isu SARA menggerakkan Afi mengunggah tulisan berjudul 'Warisan' di media sosial Facebook. Suasana yang tidak kondusif dan perpecahan baik di media sosial maupun nyata karena pengaruh isu selama Pilkada DKI Jakarta. Menurut Afi suasana di Pilkada DKI Jakarta juga menjalar ke daerah, termasuk di Banyuwangi, tempatnya tinggal.

Afi merasakan dan melihat sendiri adanya fakta bahwa isu SARA yang dihembuskan berdampak pada pertemanannya sendiri. Akibat unggahan itu, Afi mendapat serangan yang menyatakan bahwa dirinya liberal, sekuler, dan tidak berpihak kepada Islam. Akun Afi sempat tidak aktif karena diblok oleh Facebook akibat banyak yang melaporkannnya. Tulisan menohok itu berjudul 'Warisan' status Facebook bernama Afi kembali viral di dunia maya. Tulisannya memang sudah dikenal publik karena berbeda dari status remaja seusianya. Status Afi panggilan akrabnya tersebut memang sangat kritis sekaligus inspiratif. Sudah banyak tulisannya yang menjadi viral di media sosial.

Melalui tulisannya itu, Afi mengajak seluruh bangsa Indonesia untuk menjaga toleransi khususnya di media sosial yang rawan dengan gesekan-gesekan antar pengguna. Afi, menyoroti soal identitas, seperti agama, suku, ras, maupun kebangsaan merupakan warisan dari orang tua. Melalui tulisannya, Afi juga mengajak pada seluruh rakyat Indonesa untuk menghayati Pancasila, Undang-Undang Dasar (UUD) 1945, dan juga semboyan Bhinneka Tunggal Ika bahkan sampai kehidupan toleransi beragama tetap terjaga.

\section{Dimensi Praktik Sosial Budaya (Makro)}

Secara keseluruhan apabila dicermati perkembangan dunia 10 tahun terakhir menunjukkan meningkatnya intoleransi karena kekacauan di negara Timur Tengah. Kejahatan transnasionalisme mempengaruhi Indonesia. Selain itu, isu di media sosial juga mempengaruhi intoleransi. Hal tersebut mengakibatkan maraknya pemberitaan yang bohong/hoax. Kecenderungan ketidakrukunan di masyarakat meningkat, ditambah lagi isu di media sosial. Faktor lain 
penyebab ketidakrukunan yakni pengaruh tahapan Pilkada dan Pilpres. Dinamika politik baik Pilpres maupun Pilkada sering terjadi penyalahgunaan doktrin agama. Salah satunya, dalam kasus Ahok itu menimbulkan gejolak dalam kehidupan sosial bangsa Indonesia, bahkan sampai menimbulkan permusuhan antarsesama muslim.

\section{SIMPULAN DAN SARAN}

Afi dalam unggahan Facebook berjudul 'Warisan' memaparkan beberapa hal sebagai berikut. Pertama, agama, ras, suku, dan kebangsaan merupakan warisan (latar belakang) berbeda-beda. Kedua, masing-masing agama mendoktrin agama mereka yang paling benar. Ketiga, masingmasing umat beragama tidak akan ada titik temu. Ketiga, tidak usah melabeli orang masuk surga atau neraka. Keempat, latar belakang perselisihan karena saling klaim. Berdasarkan uraian itu dapat dipahami bahwa Afi menganggap latar belakang dari semua perselisihan karena masing-masing mengklaim warisan, golonganku adalah yang terbaik karena Tuhan sendiri yang mengatakannya. Apabila Tuhan berkenan kita akan disamakan dalam segala hal. Kesamaan dan keragaman tidak menjamin kerukunan. Apabila masing-masing memaksakan kitab suci sebagai dasar negara, akan timbul perpecahan. Kebebasan beragama dijamin Pancasila. Afi memiliki cara tersendiri untuk mengajak anak-anak muda yang melek teknologi untuk menjaga persatuan dan kesatuan bangsa. Unggahan Afi dalam menggunakan pertanyaan retoris, repetisi, hiperbola, metafora, Ironi, dan Sinisme.

Kondisi lingkungan sosial yang tidak kondusif dan nyaris terjadi perpecahan karena isu SARA menggerakkan Afi mengunggah tulisan berjudul 'Warisan' di media sosial (Facebook). Suasana yang tidak kondusif dan perpecahan baik di media sosial maupun dunia nyata karena pengaruh perhelatan Pilkada DKI Jakarta. Bagi Afi suasana Pilkada DKI Jakarta juga menjalar ke daerah, termasuk di Banyuwangi, tempatnya tinggal. Afi merasakan dan melihat sendiri, fakta bahwa isu SARA yang dihembuskan berdampak pada kehidupan sosial. Selain faktor internal bangsa Indonesia, ada faktor eksternal yakni dengan meningkatnya intoleransi karena kekacauan di negara Timur Tengah. Kejahatan transnasionalisme memengaruhi Indonesia. Selain itu, isu di media sosial juga memengaruhi intoleransi di Indonesia. Hal tersebut sering terjadi akibat maraknya pemberitaan yang bohong.

Tulisan Afi memang sudah dikenal publik karena berbeda dari status remaja seusianya. Status Afi memang sangat kritis 
sekaligus inspiratif. Tulisan itu mengajak seluruh bangsa Indonesia untuk menjaga toleransi khususnya di media sosial yang rawan dengan gesekan antarpengguna. Afi, menyoroti soal identitas, seperti agama, suku, ras, maupun kebangsaan merupakan warisan dari orang tua. Afi juga mengajak seluruh rakyat Indonesa untuk menghayati Pancasila, Undang-Undang Dasar 1945, dan juga semboyan Bhinneka Tunggal Ika agar toleransi beragama tetap terjaga. Tulisan Afi merupakan tulisan yang bernuansa positif dan dapat memberikan manfaat bagi pengguna internet. Semangat seperti Afi sangat diharapkan dengan begitu maraknya ujaran-ujaran kebencian di media sosial. Terlepas dari berbagai sangkaan adanya plagiasi dalam tulisan itu, Afi tetap menjadi contoh bagi semangat toleransi di tengah keberagaman bangsa Indonesia. 


\section{DAFTAR PUSTAKA}

Ahmadi F., Y. D. 2014. Analisis Wacana Kritis: Ideologi Hizbut Tahrir Indonesia Dalam Wacana Kenaikan Harga BBM 2013 di Buletin Al-Islam yang berjudul "Menaikkan Harga BBM: Nenaikkan Kemiskinan.” Metalingua: Jurnal Penelitian Bahasa, 12 (2)(Analisis Wacana Kritis), 253-265.

Budiwati, T. R. 2011. Representasi Wacana Gender Dalam Ungkapan Berbahasa Indonesia dan Bahasa Inggris: Analisis Wacana Kritis. Kawistara, Volume $\quad 1 \quad N, \quad 298-301$. https://jurnal.ugm.ac.id/kawistara/arti cle/download/3926/3207. Diakses tanggal 1 Juli 2017

Dhanu, R. 2017. Tulisan Warisan Berbuah Ancaman.

http://news.liputan6.com/read/295956

4/tulisan-warisan-berbuah-ancaman.

Diakses tanggal 6 Juni 2017

Djajasudarma, T. F. 1993. Metode Linguistik: Ancangan Metode Penelitian dan Kajian. (W. Nadeak, Ed.) (I). Bandung: PT Eresco.
Faradisa, A. N. 2017. Warisan. https://www.facebook.com/afinihaya. Diakses tanggal 1 Juli 2017

Hepburn, A., \& Potter, J. 2007. Discourse Analytic Practice. In C. Seale, G. Gobo, J. F. Gubrium, \& D. Silverman (Eds.), Qualitative Research Practice (II, p. 168). Great Britain: Cromwell Press Ltd.

Kusno, A. 2017. Discourse Analysis of Citizens Conversation in Facebook Grup Called "Bubuhan Samarinda": Identification of Potential Social Konflict. Masyarakat Dan Budaya, 19 Nomor 1, 89-104. http://jmblipi.or.id/index.php/jmb/article/view/3 91/326. Diakses tanggal 12 Juni 2017

Miles, M. B., \& Huberman, A. M. 1992. Analisis Data Kualitatif. (T. R. (Penerjemah) Rohidi, Ed.) (I). Jakarta: Penerbit Universitas Indonesia.

Moleng, L. J. 1994. Metodologi Penelitian Kualitatif (25th ed.). Bandung: PT Remaja Rosdakarya.

Purbani, W. 2009. Analisis Wacana Kritis dan Analisis Wacana Feminis. 
Ali Kusno \& Wenni Rusbiyantoro MAKNA TOPIK 'WARISAN’ DALAM UNGGAHAN FACEBOOK ...

http://staff.uny.ac.id/system/files/pen

gabdian/dr-widyastuti-purbani-

ma/analisis-wacana-kritis.pdf.

Diakses tanggal 3 Februari 2016

Rachelea, S. 2017. Jadi Viral Hingga Akunnya "Dijegal", Begini Bunyi

Status Facebook Afi yang

Kontroversial.

http://www.suratkabar.id/40353/gaya-

hidup/jadi-viral-hingga-akunnya-

dijegal-begini-bunyi-status-facebook-

afi-yang-kontroversial. Diakses

tanggal 6 Juni 2017 
Telaga Bahasa, Vol. 5, No. 2, Desember 2017: 193-212 